\title{
Self-Management and Learning Discipline of Students in Sanggar X
}

\author{
Farisan Insani ${ }^{\mathrm{a}}$, Nilam Widyarini ${ }^{\mathrm{b}}$ \\ Gunadarma University, Indonesia (farisaninsani@gmail.com) \\ Gunadarma University, Indonesia (nilam.wid@gmail.com)
}

\begin{abstract}
Self-Management are assumed to be able to improve students learning discipline in Sanggar X who lack of discipline behavior that impact on the their study and their daily basis because they choose to play, or work at their very young age. The purpose of this study is to find out whether self-management can be a way to improve learning disciplinein Sanggar X .Researchers conducted an psychoeducation assessment that was held in 4 sessions in a span of 2 weeks. This study involved 11 Sanggar X students who studied Al-Qur'an. The results of this study showed that self management can increasing the learning discipline on the students that will help Sanggar X, to continue the next phase of learning.
\end{abstract}

(C) 2018 Published by IJRP.ORG. Selection and/or peer-review under responsibility of International Journal of Research Publications (IJRP.ORG)

Keywords: Type your keywords here, separated by semicolons ;

\section{Preliminary}

Street children are the children who spend most of their times playing, working, or doing other activities on the street. The Childern who has to life on the streets are usually displaced, or discarded by their families who no longer can afford to cope with the burden due to expenses and damage to their family structure (Wahyuni, Prajanti, Alimi in Alimi, 2018).

Data from the West Java provincial government shows that in 2015 the number of street children was 9007 people, in 2016 is 6,899 people, and in 2017 is 10,017 people, although the number of street children was decreased in 2016, but in 2017 the number of street children in West Java again increased (www. 
Jabarprov.go.id). Added again according to data from (Directorate General of Rehabilitation, Social, in Suryanto, Herdiana, Chusairi, 2016) that the number of street children having a significant increase of number from year to year, 2006 by 232,894, in 2010 is 159,230, in 2011 is 67,607, in 2015 as many as 33,400 and the number of street children in 2016 reached about 4.1 million.

According to (Rafi, Ali, Aslam, 2012) the problems faced by street children are so great that they are in need to live and work in an environment that is generally dangerous to themselves, problems experienced by street children such as hunger, lack of shelter, clothing, and very lack of opportunities to get a decent education and health insurance, about $75 \%$ of street children live at home, but $25 \%$ of them spend all their time on the streets. Then there is the high probability that the children will become one of the victims of drug addiction, crime, and other behaviors that are very dangerous to themselves.

The Sanggar X taking care about 120 people ranging in age from 4 years to 18 years old, children who are in Sanggar X come from different life backgrounds and each child also has different problems such as emotions, motivation and discipline of learning, and delinquency. But in this issue the phenomenon of focused behavior is about learning discipline behavior in children who study Al-Qur'an on Sanggar X, because they think in children age 6 is the early stage where there are still many of them who have low discipline, whether it is outside or inside the classroom, which prevents them from reaching their next stage of learning.

According to Gorbunovs, Kapenieks, and Cakula (2016) there are two things that will help towards success, namely motivation and discipline, where discipline is an attitude and the ability to do an activity that should be done, but they do not want to do it, discipline can take the form of various things such as thinking before acting, completing what you have started, being responsible, working hard etc.

According to the Sanggar X learned that of the lack of discipline must be implied in their daily life. Sanggar X also said that discipline will be one of the keys children will be able to achieve good achievements in the future, and will influence discipline in their daily lives. This is in accordance with somayeh, et al (in Jefrey and Zein, 2019) that practicing discipline, becomes one of the effective factors in a learning process.

Marshall said (in Jefrey and Zein, 2017) that learning discipline is also one of the positive methods that can help and guide children to learn and gain self-control. According to Mcvitte (in Somayeh, et al. 2013) The positive thing about learning an early disciplinary approach to the child is that, in the hope that one day they can be polite, have the ability to socialize and others, and be able to be responsible in the environment.

\section{Research methods}

The subjects in this study were 11 children with the following criteria: learn to read Al-Qur'an at the Sanggar X, have learning discipline problems Aged 6-10 years; Men and women. The effectiveness testing of this study was conducted using the Wilcoxon Non Parametric Different Test which aims to find out the differences in learning disciplines before and after training. The Non Parametric different test was selected due to the small number of subjects $(<\mathrm{n} 30)$ so it did not meet the criteria in the use of different parametric tests 
The research started with the preparation stage, where an assessment process based on complaints of measuring instruments, module preparation, preparation of trainers and facilitators, and coordination with the Sanggar $\mathrm{X}$ of the training site will be carried out.

From the assessment process, there are problems in terms of discipline, especially in learning, where the lack of discipline in learning, will interfere the learning process of the students, as well as other students to be able to progress to the next level of learning. Their lack of learning discipline can be seen from their attitude in the classroom, how often they late to the class, how often they do the homework, not listening to the theacher.

Judging by the connection between one student and the others are quite well, although basically they are still children who definitely choose to play rather than study, they often doesn't care about study and often make noise in the classroom. The relationship between students, teachers and administrators is quite good, and when the children are asked if they enjoyed studying there, and the children answer Sanggar X is a really nice place.

Judging by their personal growth, Sanggar X has been acknowledge by the government, and a clear legal entity, Sanggar X has a structured program, ranging from religious coaching, skill development such as music and writing, foreign language learning activities, and has worked with an educational institution, so the children who have qualified in the specified requirement can school there..

The preparation of the training module is structured and applied with several training methods in order to effectively achieve the expected results. The training modules implemented in this study consist of manuals for trainers and materials for trainees.

This intervention was conducted as many as 4 sessions of meetings, within two weeks. Intervention is carried out in a their classroom. Each session lasts for approximately an hour and a half. In addition, members of the group are asked to set the rules that have been agreed together. Students are also required to set the punishment if the they happened to violate the rules that have been set together. The agreed rules are: (1). In terms of discipline (2). Always participating in study activities (3). Must do their homework, (4)Not late in collecting the task or homework, (5). Not making any loud noise or joking during study activities

In addition to agreeing to the rules, the group members also agreed on the penalties that must be done if they violate the rules. The punishment agreed by the group members is: (1). Asked to read the memorization chapter in the Al-Quran, (2). when the class ended, students need to finish the unfinished task or homework and and also need to finish their new task and homeworks, and need to bring all of them in the next day.

Table 1. Design of Intervention Activities

\begin{tabular}{lll}
\hline Session & Activity & Method \\
\hline I & Sharing about the problems experienced by the participants & Discussion \\
\cline { 2 - 3 } & Material about self-management & Psychoeducation \\
\hline II & Identification of Self management in participants & \\
\cline { 2 - 3 } & Material about self-management & Psychoeducation \\
\hline
\end{tabular}




\begin{tabular}{lll}
\hline III & \multicolumn{2}{l}{ Practicing about self management on daily basis } \\
\cline { 2 - 3 } & Material about self-management & Psychoeducation \\
\hline IV & Review, and provide motivation to participants & Lecture \\
\cline { 2 - 3 } & $\begin{array}{l}\text { Provide positive learning to participants through short } \\
\text { films }\end{array}$ & Video \\
&
\end{tabular}

\section{Result and Discussion}

Based on the results of the assessment that has been done, it is known the problem that occurs on the students in Sanggar X who study Al-Qur'an it is because most of them work as street musicians, traders in the market, and a beggar, and others who still want to play instead of studying, that makes some of them can't focus themselves on study, do their homeworks, come on time, and not making any loud noise, joking, and playing with other students when studying on the class. Before the intervention is started, a pre-test is given to the students and after the intervention is given a post-test, for learning discipline problems after they having self management assessment it is illustrated in the following graph:

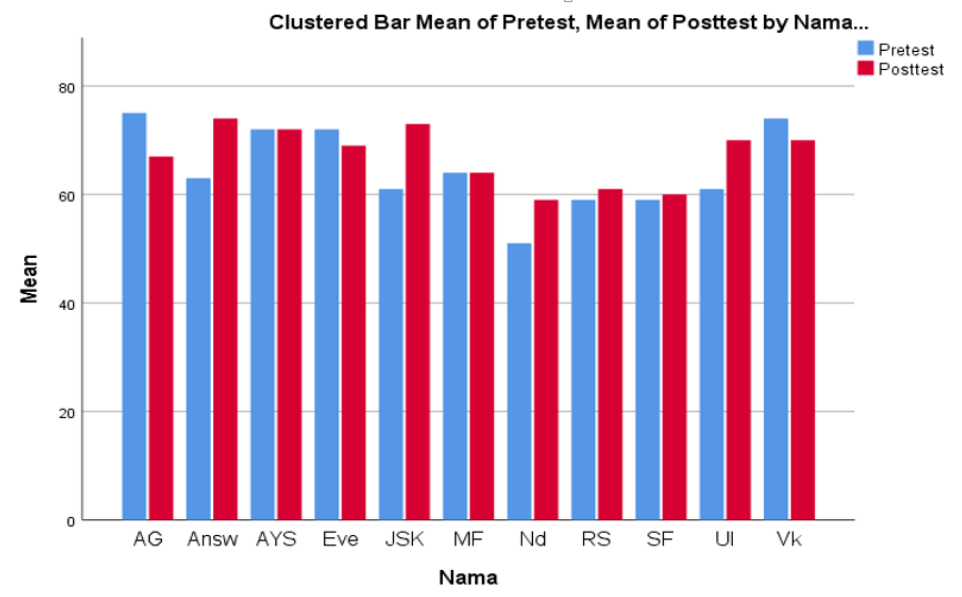

Picture 1. The result of the self-management questionnaire pre-test and post-test 11 student who study Al-Quran.

The assessment on the diagram is the amount of disciplinary conduct performed by the students in terms of discipline. Based on the results of observations before and after the intervention was conducted (pre-test) 6 members of the group showed an increase in discipline levels in the study group, 2 people were in a stable level unchanged, and 3 people experienced a decrease in discipline level. 
Descriptive Statistics

\begin{tabular}{lr|r|r|r|r} 
& $\mathrm{N}$ & \multicolumn{1}{|c|}{ Mean } & \multicolumn{1}{|c}{ Std. Deviation } & \multicolumn{1}{c}{ Minimum } & Maximum \\
\hline Pretest & 11 & 61.00 & 5.329 & 51 & 72 \\
\hline $\begin{array}{l}\text { Posttes } \\
\mathrm{t}\end{array}$ & 11 & 67.73 & 4.839 & 60 & 74 \\
\hline
\end{tabular}

Table 2. Average Pre-test and Post-test results

\section{Test Statistics $^{\mathrm{a}}$}

Pretest- Posttest

\begin{tabular}{lr}
\hline$Z$ & $-2.668^{\mathrm{b}}$ \\
\hline Asymp. Sig. (2-tailed) & .008 \\
\hline
\end{tabular}

Table 3. Statistics based on the Wilcoxon Signed Rank Test

Results showed significance of $0.008(\mathrm{p}<0.01)$. These results mean there are significant differences in the level of discipline on the students of Sanggar X between pre-test and post-test. The results of the data analysis through wilcoxon different tests can be viewed through table 2. Judging by the comparison of the above average grades, it can be said that the training of improving discipline of learning students in Sanggar $\mathrm{X}$ is effective because the average level of discipline learned after training becomes higher than the average level of discipline before training

\subsection{Discussion}

Based on the observation results after the post-test activity, it was seen that the majority of students experienced a change in behavior in a positive direction. students begin be able to learn how to be disciplined in studying and learning activities. The disciplined behavior is also on the increasing. This is can be seen from the number of disciplinary violations committed is deacreasing after the assesment. Teachers also said that almost all of the group members' behavior changed in a positive direction. However, teachers should always directing the students in order to maintain and improve the positive behavior, especially to members of the group who still do not showing an increased level of discipline.

Some of the things thatsuccessfully support this intervention activities are: 1) Group members feel that the problems they experience related to disciplinary behavior interfere with their learning activities. This 
gives the students motivation to change to the positive direction. 2) The rules shall be strictly implemented and made by all the students agreement, as well as the penalties that will be received. This makes the students aware of complying with the rules and not feeling compelled. 3) In addition to punishment, rewarding or rewarding also adds motivation to the students in order to motivate them to be able to change for the better 4) Using video material in explaining to makes it easier for them to understand the study.

The success of this intervention activity according to Pardey's opinion (2007) in his book that saying Coaching and training your work teaam explains there are several things that are the deciding factor in the success of a training, namely: 1) Before delivering the material, the facilitator or presenter of the material introduces in advance the topic to be discussed. 2) Clear material delivery so that trainees can understand and absorb all materials provided at the time of training and can apply them in daily life. 3) Always give exercises at the end of each session. 4) There is an evaluation process after the training activity is carried out, which aims to know how much influence the training has on the behavior changes of the trainees.

During the implementation of intervention activities, researchers found it difficult to convey material to the students. The difficulty is that the students who are generally elementary school children, there are still many who often joking around, so we do a mutual agreement, if anyone plays or joking when the material is in progress then, they will be given some question by researchers.

Based on the results of the intervention evaluation, most members of the group showed a fairly good change in behavior. Some members of the group experienced an increase in disciplinary behavior. However, some members of the group showed no change in behavior at all prior to the intervention or after the intervention activity.

\section{Conclusions and recommendations}

\subsection{Conclusions}

Based on the results of assessments that have been made for 11 students, it is known that the problem experienced by all of them is the lack of disciplined behavior. Because there are still many of them who have low discipline, whether it is inside or outside the classroom, such as it is very difficult to ask them to be silent and pay attention during study time, as well as the number of children who do not do their homework that given 4 times a week. This problem makes the teacher is difficult to move and teach them to the next stage of learning. According to teachers this problem happend because they love to play more - and when they come home from study in Sanggar X some of them return to work as beggars, beggars, scavengers with their parents.

Based on the problem, to solve the problem and aiming to increasing the ability of self management to improve disciplined behavior. This intervention was conducted in four meetings. Based on the results of the interventions, it was obtained that most of the students experienced change in good behavior in terms of disciplined behavior in learning. Most of them have been able to implement the ways how to improve their ability to be disciplined, especially when studying

\subsection{Recommendations}

For students who have attended training is expected to be able to continue and apply what has been learned and obtained during the training in daily life. It is important that children are able to apply their discipline not only in learning, but in each of their daily activities. 


\section{References}

Citra, F.A., Widyarini., N. (2015). Pelatihan peningkatan harga diri pada remaja panti asuhan sub unit perlindungan sosial asuhan anak, cibalagung, bogor. Jurnal psikologi, 8(2), 91- 103.

Dinas Sosial Provinsi Jawa Barat (2020). Jumlah anak jalanan. In access on January 11 , 2020 from http://satudata.jabarprov.go.id/satudata/indikator/IS_SOSBUD/1286

Rafi, S., Ali, M., Aslam, A. M. (2012). The problem of street children : case study of sargodha city. American international journal of contemporary research, 2(2), $194-197$.

Suryanto, Herdiana, I., Chusairi, A. (2006). Deteksi dini masalah psikologis anak jalanan pada orang tua asuh di rumah singgah. Jurnal psikologi dan kesehatan mental, 1 (2), 85-96.

Wahyuni, I.N., Prajanti, W. D. S., Alimi, Y.N., (2018). Social action of street childern to sustain their life in pati regency. Journal of education social studies, 7(1), 67-74.

Miltenberger, RG. 2012. Behavior Modification (Principles and Procedures). Fifth Edition. USA: Wadsworth Cengange Learning. 